\title{
The Learning of E-Sustainability Competences: A Comparative Study between Future Early Childhood and Primary School Teachers
}

\author{
Mayra Urrea-Solano*(D), María J. Hernández-Amorós (D), Gladys Merma-Molina and Salvador Baena-Morales $\mathbb{D}$ \\ Department of Didactic General and Specific Training, University of Alicante, 03690 San Vicente del Raspeig, \\ Spain; josefa.hernandez@ua.es (M.J.H.-A.); gladys.merma@ua.es (G.M.-M.); Salvador.baena@ua.es (S.B.-M.) \\ * Correspondence: mayra.urrea@ua.es
}

check for

updates

Citation: Urrea-Solano, M.;

Hernández-Amorós, M.J.;

Merma-Molina, G.; Baena-Morales, S.

The Learning of E-Sustainability

Competences: A Comparative Study between Future Early Childhood and

Primary School Teachers. Educ. Sci.

2021, 11, 644. https://doi.org/

10.3390/educsci11100644

Academic Editor: João Piedade

Received: 30 August 2021

Accepted: 11 October 2021

Published: 14 October 2021

Publisher's Note: MDPI stays neutral with regard to jurisdictional claims in published maps and institutional affiliations.

Copyright: (c) 2021 by the authors. Licensee MDPI, Basel, Switzerland. This article is an open access article distributed under the terms and conditions of the Creative Commons Attribution (CC BY) license (https:/ / creativecommons.org/licenses/by/ $4.0 /)$.

\begin{abstract}
Digital technologies play a key role in the fulfilment of the 2030 Agenda. However, their contribution to this goal depends on the digital culture of society. In this context, future teachers' knowledge of e-sustainability is of paramount importance, as the responsible and sustainable behaviour of future generations largely depends on their skills in this area. Therefore, this study aimed to identify the existence of possible differences in digital competences in sustainability among trainee teachers. The study involved the participation of 348 students in the 2nd year of their Bachelor's Degrees in Early Childhood and Primary Education at the University of Alicante (Alicante, Spain), who filled out a questionnaire on this topic. The SPSS v. 25 statistical programme, with which a comparative analysis was carried out, was used to process the data. On the basis of the results, the students of the Bachelor's Degree in Early Childhood Education generally presented a higher level of e-sustainable competences, especially with regard to general competences and the economic dimension of digital sustainability. Despite this, and given the small size of the differences, we conclude that there is a need to design didactic proposals to favour the acquisition of these competences among future teachers at both stages.
\end{abstract}

Keywords: digital competences; sustainability; initial teacher training; early childhood education; primary education

\section{Introduction}

The inequalities and imbalances that have affected the planet over the last few decades have created an urgent need for effective measures to combat their devastating effects [1]. As a result, and in an attempt to achieve well-being and prosperity for the whole of humanity, in 2015 the United Nations (UN) proposed the 2030 Agenda, a roadmap for progress towards a fairer and equal world [2]. With this framework for action and the 17 Sustainable Development Goals (SDGs) that comprise it, most of the world's countries committed, among other aspects, to eradicate extreme poverty (SDG 1), achieve quality education (SDG 4), and eliminate all forms of discrimination (SDG 5) by 2030. However, more than five years after this declaration, it must be acknowledged that progress in this direction has been rather timid and scarce and that, therefore, this ambitious horizon seems increasingly distant and diffuse [3].

Faced with this situation, and given the threat that COVID-19 has posed to the achievement of the 2030 Agenda [4,5], the UN has recently urged the international community as a whole to accelerate its efforts to put an end to the major problems affecting humanity [6]. Thus, 2020 marked the start of the 'Decade of Action', an opportunity in extremis to address the major challenges facing our society and to promote equity, justice and prosperity. Undoubtedly, in this race, Education for Sustainable Development (ESD) becomes one of the most effective means to promote the acquisition of attitudes, behaviours, and values that are respectful and environmentally friendly [7-10]. In fact, as evidenced by the recent study 
by Sánchez-Carracedo et al. [11], its implementation with Educational Science students is especially beneficial to increase their capacity for critical thinking, sustainable use of resources, participation in social transformation processes, and ethical principles. This learning is also greatly enriched when active methodologies are used in the process [12-15].

In this context, Information and Communication Technologies (ICTs) represent a particularly significant tool to favour socioeconomic progress, but also to contribute to the learning of sustainability $[16,17]$. In fact, several literature reviews in recent years have echoed its extraordinary potential in this field [18-20]. Thus, its remarkable value has been shown, among other aspects, to promote the development of environmental awareness [21] or to undertake actions to mitigate climate change [22]. It is no less true, however, that its excessive and disproportionate use can be harmful to the economic, social, and environmental balance of the planet. First of all, the manufacturing processes associated with ICT often lead to serious problems of pollution and the depletion of natural resources, as well as new forms of slavery [23,24]. Moreover, the impact of the digital divide is particularly damaging for the most vulnerable groups, who experience serious difficulties in accessing the possibilities offered by technological devices [25-28]. Hence, digital competences training in sustainability has become a key element for the achievement of the 2030 Agenda [29]. According to Sánchez et al. [30], this type of skill is specifically related to four domains (Figure 1): (1) the critical contextualisation of knowledge and its link to social, economic, and environmental problems; (2) the sustainable use of technological resources and the prevention of their negative social, environmental and economic effects; (3) participation in collaborative processes that favour digital sustainability; and (4) the use of ethical principles related to personal and professional behaviour.

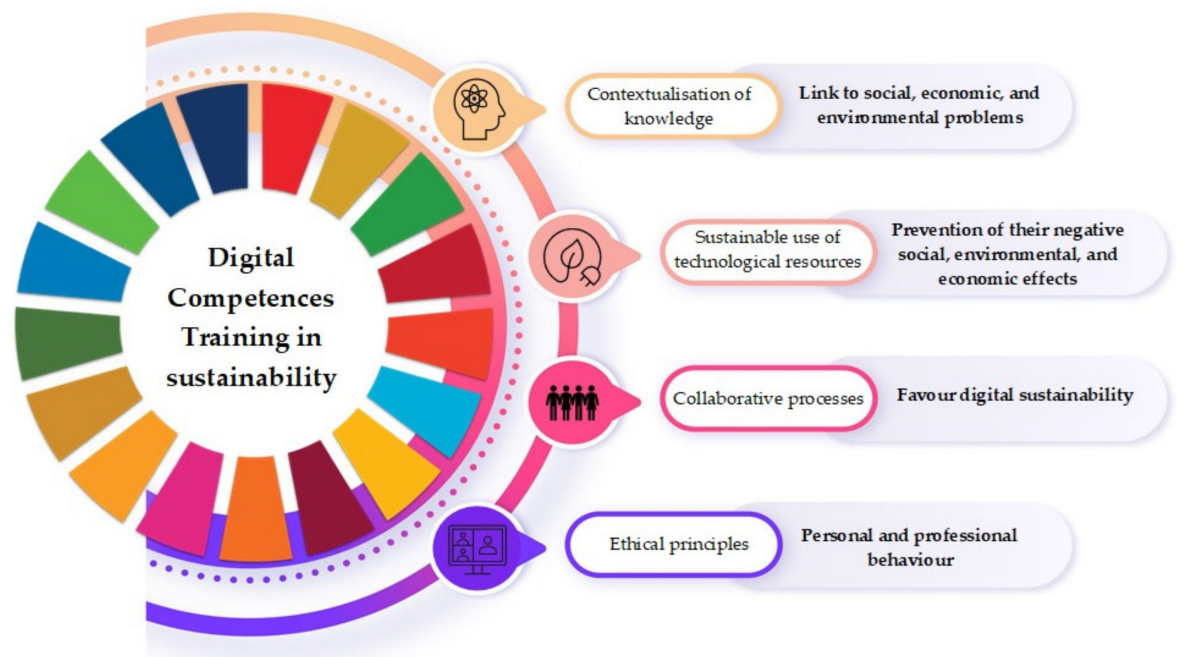

Figure 1. Areas of training in digital competencies in sustainability. Based on Sánchez et al. [30].

With regard to future teachers, these competences acquire even more relevance, since the behaviour of future generations is largely mediated by teacher training in this area [31,32]. In fact, Dziminska et al. [33] and Zamora-Polo and Sánchez-Martín [34] underline the important role that Higher Education institutions have to play in this field. Despite this, several studies emphasise the weak integration of sustainability in university curricula [11,35,36]. For example, in the analysis carried out by Muñoz-Rodríguez et al. [37] of students of Education Sciences in Spain, it was possible to verify the deficiencies in the curricular treatment of sustainability. Even the students themselves recognise their lack of knowledge and admit that they do not feel qualified to incorporate this approach in their future professional performance [38,39].

This shortage of training seems to be most pronounced in relation to the acquisition and development of digital competences. In fact, several studies highlight the limited training of future teachers in this area [40-43]. According to Gewerc and Montero [44], the 
profile of use is rather of an instrumental and informational nature, without reaching the skills necessary for the production of authentic knowledge. This low level of proficiency has been observed especially in future teachers of Early Childhood and Primary Education who, in both cases, seem to have a low level of digital competences [45]. However, the most worrying aspect is that this lack of technological skills remains virtually unchanged throughout their initial training. That is, both at the beginning and at the end of their undergraduate studies, their knowledge of digital content creation and problem-solving is very limited [46]. This situation is also particularly evident with regard to the use of emerging technologies [47].

On the other hand, if a comparative perspective is adopted and the degree of digital proficiency among future Early Childhood and Primary School teachers is analysed, it seems to be the latter who define themselves as more competent in ICT [48]. At the same time, it is also this group who show a higher level of awareness and individual responsibility for sustainability. As research by Estrada-Vidal et al. [49] has shown, trainee teachers at this stage understand that individuals, as integral members of institutions, should be the architects of transformation and social change, while their Early Childhood counterparts prefer effort and collective work. Despite this, and as Marcos-Merino et al. [50] rightly point out, it is necessary to optimise training in sustainability for Primary Education students, as their knowledge of the economic and environmental dimensions of sustainability is very limited.

Some of the strategies that are currently implemented for this purpose undoubtedly make use of the potential of digital tools. Thus, for example, the use of the e-portfolio is a particularly useful resource for learning about sustainability, as it promotes participation, awareness, and critical reflection [51]. Other experiences are based, instead, on the possibilities offered by emerging technologies, such as robotics. In fact, holistic training in this type of methodology helps future teachers to acquire the skills necessary for the design of interdisciplinary sustainability projects, while improving their digital competences [52].

Within this framework of considerations, and considering the close relationship between knowledge, attitudes and sustainable behaviours [50], this study aimed to identify possible differences in the learning of e-sustainability competences among future Early Childhood and Primary School teachers. The recognition of such discrepancies allows the design of didactic proposals that are better adjusted and more in line with the real needs of trainee teachers. Moreover, the identification of these divergences will contribute to the sustainability of the curricula of future teachers and, therefore, to the strengthening of the role that Higher Education institutions must play in this area.

\section{Materials and Methods}

The appropriateness of quantitative methodology for the study of teachers' professional development in terms of sustainability meant that the research was designed with a quantitative approach [53]. Specifically, a comparative analysis was carried out [54].

\subsection{Sample}

Of the 690 students of Bachelor's Degrees in Early Childhood Education (BDECE) and Primary Education (BDPE) at the Faculty of Education of the University of Alicante (UA) enrolled in the subject of Curriculum Development and Digital Classrooms (CDDC), 348 participated (50.43\% of the total population). Of these, $66.6 \%$ belonged to the BDPE and $73.5 \%$ were women, which is consistent with the feminization of this area of knowledge [55]. At the time of the data collection, $46.4 \%$ were $20-25$ years of age and $45.1 \%$ were under 20 years of age. Only a small group of participants were over 25 years of age (8.6\%).

According to the curricula of both degrees, CDDC is a core subject of 6 ECTS ( 0.6 theoretical credits, 1.80 practical credits and 3.60 distance-base hours) that is taken in the second year. It seeks to provide future teachers of Early Childhood and Primary Education with the knowledge and skills necessary to facilitate the didactic integration of technology in the classroom. It consolidates and expands students' instrumental knowledge, encour- 
ages their reflection on the educational integration of ICT, and promotes their continuing education in this area.

\subsection{Instrument}

An adaptation of the questionnaire by Sánchez et al. [56] was used to collect the data. The objective of this instrument was to assess digital competences in sustainability in ICT engineering degrees. As a result, and with the aim of adapting the questionnaire to the pedagogical field, 9 of the 34 items it contained were eliminated. Specifically, those items most closely related to the management of technological projects (items 10 and 21-28) were removed.

Thus, the final instrument consisted of 25 Likert-type items, whose scale ranged from 1 ("Strongly disagree") to 5 ("Strongly agree"). Three closed questions were added to these to collect information on gender, age, and degree studied. The final version of the questionnaire was structured in five dimensions: (1) Sociodemographic information (three items); (2) general competences in e-sustainability (ten items); (3) digital competences in environmental sustainability (five items); (4) digital competences in social sustainability (four items) and (5) digital competences in economic sustainability (six items). The final instrument was validated by a team of judges, consisting of three female expert professors in educational research at the UA. They were invited to revise the questionnaire due to: (1) their extensive career and recognition in the field of quantitative analysis and teacher training; and (2) the ease of accessing them, given that they are researchers from the same center as the authors of the study. We created an online survey with the items of the instrument using Google Forms and sent it to the professors via email. The aim was for the professors to assess the relevance of the items for each of the dimensions and for the instrument as a whole. The following criteria were used as indicators: (1) not at all relevant (the item could be eliminated without affecting the measurement), (2) useful (the item had relevance, but was not essential) and (3) essential (the item should be included). In addition, they were given the option of making a qualitative assessment of the syntax and clarity of the wording of each item. Based on their expert judgment, some grammatical issues had to be modified. This, together with the high internal consistency score presented by the instrument through the calculation of Cronbach's alpha $(\alpha=0.91)$, motivated its use in the study.

In order to facilitate its dissemination, the questionnaire was developed in a digital format using Google Forms. The choice of this application was justified by the multiple features it offers, such as automatic data storage, its free nature, and the unlimited number of responses it allows [57].

\subsection{Procedure}

In order to obtain the required authorisation, the female lecturer who coordinates the CDDC teaching in the Faculty of Education of the UA was contacted. Subsequently, six CDDC professors administered the questionnaire to their respective groups of students. This application was carried out through the virtual campus of the UA at the beginning of the unit. The participating students completed the instrument during normal class hours, individually and with the virtual presence of one of the members of the research group. The latter was responsible for informing them about the aim of the study and providing the necessary instructions for filling in the questionnaire. The response time was approximately $20 \mathrm{~min}$. The procedure followed was the same for both sample groups (BDECE and BDPE).

With regard to the ethics of the research, the study complied with the basic principles of the Declaration of Helsinki. The voluntary nature of participation and the anonymity and confidentiality of the information provided were guaranteed at all times.

SPSS Statistics 25 software was used for data processing and analysis, through which a comparative study was carried out. For this purpose, the non-parametric Mann-Whitney $U$ test was applied. The choice of this technique was motivated, above all, by the lack of normality in the responses and the ordinal level of measurement of the data of the 
study variables (items). The normality of the distribution was evaluated by means of the Kolmogorov-Smirnov test $(p<0.05)$. In addition, the Mann-Whitney $U$ technique facilitates the understanding of the association between a nominal dichotomous variable and another ordinal variable with numerical reading (1-5). Its use made it possible to test the hypothesis of the equality of mean ranks in the different item ratings according to the degree studied. Likewise, in order to distinguish the effect size, the R-index was calculated. According to this, a score between 0.10 and 0.29 indicated a small effect; between 0.30 and 0.49 indicated a medium effect; between 0.50 and 0.69 indicated a large effect; and $\geq 70$ indicated a very large effect [58].

\section{Results}

The findings are presented according to the integral dimensions of the data collection instrument.

\subsection{The Learning of General Competences for E-Sustainability According to the Degree Studied}

In relation to general e-sustainability competences, statistically significant differences were observed between some items on the scale (Table 1). In all cases, the BDECE students obtained higher mean ranks than the BDPE students, which means that BDECE students have a higher degree of mastery of the skills and abilities related to this area. Specifically, male and female BDECE students have a deeper knowledge of the social, economic and environmental problems caused by ICTs, as well as a greater mastery of the concepts of creativity and innovation and their associated techniques. In addition, they are also more capable of suggesting ideas to make a project sustainable, considering the environmental, economic, and social dimension of sustainability and its ethical principles. Nevertheless, it should be noted that in all cases the effect size of the differences was small.

Table 1. General competences in e-sustainability according to the degree studied.

\begin{tabular}{|c|c|c|c|c|c|c|}
\hline Items & Degree & Mean Rank & $U$ & $p$ & $z$ & $r$ \\
\hline $\begin{array}{l}\text { 1. I know the causes, consequences and solutions proposed in the } \\
\text { literature regarding the social, economic and environmental } \\
\text { problems generated by ICTs }\end{array}$ & $\begin{array}{l}\text { BDECE } \\
\text { BDPE }\end{array}$ & $\begin{array}{l}197.37 \\
162.27\end{array}$ & $10,687.5$ & 0.001 & -3.30 & -0.17 \\
\hline $\begin{array}{l}\text { 2. In solving an ICT-related problem, I can analyze sustainability } \\
\text { from an environmental, social and economic perspective }\end{array}$ & $\begin{array}{l}\text { BDECE } \\
\text { BDPE }\end{array}$ & $\begin{array}{l}187.25 \\
167.35\end{array}$ & $11,861.5$ & 0.060 & -1.87 & - \\
\hline $\begin{array}{l}\text { 3. I am able to identify the causes of an ICT-related problem and } \\
\text { foresee its possible consequences. I can relate the problem to other } \\
\text { known problems and solutions already applied }\end{array}$ & $\begin{array}{l}\text { BDECE } \\
\text { BDPE }\end{array}$ & $\begin{array}{l}180.64 \\
170.67\end{array}$ & $12,628.0$ & 0.318 & -0.998 & - \\
\hline $\begin{array}{l}\text { 4. I know the concepts of creativity and innovation and strategies to } \\
\text { develop them }\end{array}$ & $\begin{array}{l}\text { BDECE } \\
\text { BDPE }\end{array}$ & $\begin{array}{l}198.02 \\
161.94\end{array}$ & $10,612.0$ & $<0.001$ & -3.70 & -0.19 \\
\hline $\begin{array}{l}\text { 5. I understand innovation and idea generation techniques and } \\
\text { participate when they are used }\end{array}$ & $\begin{array}{l}\text { BDECE } \\
\text { BDPE }\end{array}$ & $\begin{array}{l}194.51 \\
163.70\end{array}$ & $11,018.5$ & 0.002 & -3.08 & -0.16 \\
\hline $\begin{array}{l}\text { 6. I am able to bring new ideas and solutions to a technological } \\
\text { project to make it more sustainable }\end{array}$ & $\begin{array}{l}\text { BDECE } \\
\text { BDPE }\end{array}$ & $\begin{array}{l}191.29 \\
165.32\end{array}$ & $11,392.0$ & 0.014 & -2.46 & -0.13 \\
\hline $\begin{array}{l}\text { 7. I am able to propose sustainable ICT projects, taking into account, } \\
\text { in a holistic way, environmental, economic and social aspects }\end{array}$ & $\begin{array}{l}\text { BDECE } \\
\text { BDPE }\end{array}$ & $\begin{array}{l}200.88 \\
160.50\end{array}$ & $10,279.5$ & $<0.001$ & -3.77 & -0.20 \\
\hline 8. I know the ethical principles related to sustainability & $\begin{array}{l}\text { BDECE } \\
\text { BDPE }\end{array}$ & $\begin{array}{l}185.61 \\
168.17\end{array}$ & $12,051.0$ & 0.102 & -1.63 & - \\
\hline $\begin{array}{l}\text { 9. I can assess the implications of ethical principles related to } \\
\text { sustainability in an ICT project }\end{array}$ & $\begin{array}{l}\text { BDECE } \\
\text { BDPE }\end{array}$ & $\begin{array}{l}186.70 \\
167.62\end{array}$ & $11,925.0$ & 0.071 & -1.80 & - \\
\hline $\begin{array}{l}\text { 10. I am able to propose solutions and strategies to promote ICT } \\
\text { projects consistent with ethical principles related to sustainability }\end{array}$ & $\begin{array}{l}\text { BDECE } \\
\text { BDPE }\end{array}$ & $\begin{array}{l}192.58 \\
164.67\end{array}$ & $11,242.5$ & 0.008 & -2.65 & -0.14 \\
\hline
\end{tabular}

\subsection{The Learning of Digital Competences in Environmental Sustainability According to the Degree Studied}

When it came to assessing their digital competences in environmental matters (Table 2), it was again the BDECE students who claimed to have a greater knowledge of sustainable 
technologies applicable to ICT projects and the role that this type of tool plays in the sustainability of the planet. However, the magnitude of these differences was also small.

Table 2. Competences in the environmental dimension of e-sustainability according to the degree studied.

\begin{tabular}{|c|c|c|c|c|c|c|}
\hline Items & Degree & Mean Rank & $u$ & $p$ & $z$ & $r$ \\
\hline $\begin{array}{l}\text { 1. I understand the environmental costs of ICT-related products throughout } \\
\text { their life cycle }\end{array}$ & $\begin{array}{l}\text { BDECE } \\
\text { BDPE }\end{array}$ & $\begin{array}{l}183.62 \\
169.17\end{array}$ & $12,282.0$ & 0.181 & -1.33 & - \\
\hline $\begin{array}{l}\text { 2. I know how to measure the environmental impact of ICT use with the } \\
\text { appropriate indicators }\end{array}$ & $\begin{array}{l}\text { BDECE } \\
\text { BDPE }\end{array}$ & $\begin{array}{l}187.31 \\
167.32\end{array}$ & $11,854.5$ & 0.063 & -1.86 & - \\
\hline $\begin{array}{l}\text { 3. I can assess the impact (positive and negative) of ICT products and } \\
\text { services on society and on the sustainability of the planet }\end{array}$ & $\begin{array}{l}\text { BDECE } \\
\text { BDPE }\end{array}$ & $\begin{array}{l}185.09 \\
168.43\end{array}$ & $12,111.0$ & 0.101 & -1.63 & - \\
\hline $\begin{array}{l}\text { 4. I know the "sustainable" technologies applicable to an ICT project and the } \\
\text { environmental impact indicators }\end{array}$ & $\begin{array}{l}\text { BDECE } \\
\text { BDPE }\end{array}$ & $\begin{array}{l}197.64 \\
162.13\end{array}$ & $10,656.0$ & 0.001 & -3.29 & -0.17 \\
\hline $\begin{array}{l}\text { 5. I know the strategic role of ICTs in the sustainability of the planet, as well } \\
\text { as the concepts of social justice, reuse of resources and circular economy }\end{array}$ & $\begin{array}{c}\text { BDECE } \\
\text { BDPE }\end{array}$ & $\begin{array}{l}196.21 \\
162.85\end{array}$ & $10,822.0$ & 0.002 & -3.14 & -0.16 \\
\hline
\end{tabular}

\subsection{The Learning of Digital Competences in Social Sustainability According to the Degree Studied}

With regard to social e-sustainability, once again the BDECE students obtained the highest mean ranks (Table 3). Specifically, they showed a greater ability to value the contribution of ICT projects to the improvement of society. Again, the effect size was small.

Table 3. Competences in the social dimension of e-sustainability according to the degree studied.

\begin{tabular}{|c|c|c|c|c|c|c|}
\hline Items & Degree & Mean Rank & $u$ & $p$ & $z$ & $r$ \\
\hline $\begin{array}{l}\text { 1. I know the issues related to social justice, equity, diversity and } \\
\text { transparency }\end{array}$ & $\begin{array}{l}\text { BDECE } \\
\text { BDPE }\end{array}$ & $\begin{array}{l}181.61 \\
170.18\end{array}$ & $12,515.0$ & 0.276 & -1.08 & - \\
\hline $\begin{array}{l}\text { 2. I know the direct and indirect consequences of ICT products and } \\
\text { services on society }\end{array}$ & $\begin{array}{l}\text { BDECE } \\
\text { BDPE }\end{array}$ & $\begin{array}{l}182.16 \\
169.90\end{array}$ & $12,452.0$ & 0.218 & -1.23 & - \\
\hline $\begin{array}{l}\text { 3. I understand the need to introduce social justice, equity, diversity } \\
\text { and transparency in ICT projects }\end{array}$ & $\begin{array}{l}\text { BDECE } \\
\text { BDPE }\end{array}$ & $\begin{array}{l}181.25 \\
170.36\end{array}$ & $12,557.5$ & 0.292 & -1.05 & - \\
\hline $\begin{array}{l}\text { 4. I can assess whether an ICT project contributes to improving the } \\
\qquad \text { common good of society }\end{array}$ & $\begin{array}{l}\text { BDECE } \\
\text { BDPE }\end{array}$ & $\begin{array}{l}191.44 \\
165.24\end{array}$ & $11,375.5$ & 0.007 & -2.70 & -0.14 \\
\hline
\end{tabular}

3.4. The Learning of Digital Competences in Economic Sustainability According to the Degree Studied

With regard to digital competences in economic sustainability, statistically significant differences were observed between the participants from both degrees (Table 4). Once again, the BDECE students reported a higher level knowledge about accessibility, ergonomics, and security issues in ICT projects, a greater ability to evaluate these features in an ICT product, and a greater consideration of these aspects in technological solutions. Similarly, it was once again the male and female students of this degree who claimed to have a deeper knowledge of technological tools for collaborative work and greater expertise in their use. 
Table 4. Competences in the economic dimension of e-sustainability according to the degree studied.

\begin{tabular}{|c|c|c|c|c|c|c|}
\hline Items & Degree & Mean Rank & $u$ & $p$ & $z$ & $r$ \\
\hline $\begin{array}{l}\text { 1. I know the issues related to accessibility, ergonomics and safety of } \\
\text { ICT products and projects }\end{array}$ & $\begin{array}{l}\text { BDECE } \\
\text { BDPE }\end{array}$ & $\begin{array}{l}183.62 \\
169.17\end{array}$ & $12,282.0$ & 0.181 & -1.33 & - \\
\hline $\begin{array}{l}\text { 2. I can assess the degree of accessibility, ergonomic quality, safety } \\
\text { level and societal impact of an ICT product or service }\end{array}$ & $\begin{array}{l}\text { BDECE } \\
\text { BDPE }\end{array}$ & $\begin{array}{l}187.31 \\
167.32 \\
\end{array}$ & $11,854.5$ & 0.063 & -1.86 & - \\
\hline $\begin{array}{l}\text { 3. I take into account accessibility, ergonomics and safety aspects in } \\
\text { technological solutions }\end{array}$ & $\begin{array}{l}\text { BDECE } \\
\text { BDPE }\end{array}$ & $\begin{array}{l}185.09 \\
168.43\end{array}$ & $12,111.0$ & 0.101 & -1.63 & - \\
\hline $\begin{array}{l}\text { 4. I know the concept, examples and tools of collaborative work in } \\
\text { the field of ICTs }\end{array}$ & $\begin{array}{c}\text { BDECE } \\
\text { BDPE }\end{array}$ & $\begin{array}{l}197.64 \\
162.13\end{array}$ & $10,656.0$ & 0.001 & -3.29 & -0.17 \\
\hline $\begin{array}{l}\text { 5. I can assess the implications of collaborative work in an ICT } \\
\text { project }\end{array}$ & $\begin{array}{c}\text { BDECE } \\
\text { BDPE }\end{array}$ & $\begin{array}{l}196.21 \\
162.85\end{array}$ & $10,822.0$ & 0.002 & -3.14 & -0.16 \\
\hline 6. I know how to use collaborative work tools related to ICT projects & $\begin{array}{l}\text { BDECE } \\
\text { BDPE }\end{array}$ & $\begin{array}{l}193.09 \\
164.42\end{array}$ & $11,184.0$ & 0.003 & -2.92 & -0.15 \\
\hline
\end{tabular}

\section{Discussion}

Fulfilling the 2030 Agenda necessarily requires the improvement of digital competences across society. In this scenario, the training of future teachers becomes a fundamental element, since the attitudes and behaviours of subsequent generations are, to a large extent, dependent on their knowledge of the sustainable use of technology [31,32]. Based on this premise, the aim of this study was to identify the existence of possible differences in the learning of digital competences in sustainability among future Early Childhood and Primary School teachers. In this sense, and according to the results, it is the former who seem to have a higher degree of e-sustainable skills and abilities. However, the discrepancies were particularly marked in general knowledge, especially with regard to the design of sustainable ICT projects, the capacity for creativity and innovation, and the understanding of the problems generated by technological tools. Nevertheless, these differences were less noticeable in economic, environmental and, in particular, social areas, where there were hardly any differences between the students of both degrees. These findings, however, contradict most of the accumulated research in this area. Thus, in contrast to the study by Briones et al. [48], it was the future Early Childhood Education teachers who claimed to have a higher level of digital competences. On the other hand, and in relation to sustainability, the evidence from the present research also contradicted the results of Estrada-Vidal et al. [49]. In contrast to their study, BDECE students again reported higher proficiency in sustainability.

The possible explanations for these discrepancies are multiple and varied. First of all, the divergences in the configuration of the curricula of both degrees must be considered. Although both pursue the same goal, i.e., to provide students with the knowledge and skills necessary for the exercise of teaching, the peculiarities of each stage entail different subjects, competences and content [59,60]. However, as highlighted by Dziminska et al. [33] and Zamora-Polo and Sánchez-Martín [34], Higher Education institutions, committed to achieving the 2030 Agenda, must make additional efforts to ensure the integration of the SDGs in the syllabuses of all curricula. Only in this way will they fulfil their commitment to society and contribute to building a more supportive and sustainable future [37,39].

Another possible reason for these differences lies in the characteristics of the students in each speciality. In this sense, it is worth highlighting the clear feminisation of BDECE students and the proactive tendency shown by women towards sustainability $[9,15,61]$. Hence, these variations in results may also be closely related to some gender issues. In addition, the results only reflect the participants' perception of themselves, so that, as in other studies of a similar nature, there could be some divergences from their real level of e-sustainability competences [41]. However, considering the small size of the differences 
identified and the lack of training of future teachers in this area, the need to strengthen their knowledge in digital sustainability is highlighted [44-46,49,50].

A possible strategy for this involves the design of training activities that combine the potential of ICT and the reflective, collaborative, and experiential nature of active methodologies $[12,15]$. Among other actions, and considering the existing evidence, a good alternative could be the use of educational robotics and Project-Based Learning (PBL). Through this type of experience, future teachers will not only have the opportunity to develop their digital competences and acquire knowledge about programming, but will also be able to learn how to develop interdisciplinary projects to work on sustainability and the responsible use of technology [52]. Another valid formula for this objective is training through massive open online courses (MOOCs), which, according to Ortega-Sánchez and Gómez-Trigueros [17], are particularly valid for optimising teacher training in SDGs formation. However, regardless of the methodology used, one of the basic requirements that this type of initiative must meet is the commitment and involvement of responsible teachers, as their example stimulates motivation and the meaningfulness of learning [39].

\section{Conclusions}

This study presented a comparative analysis of the learning of e-sustainability competences between BDPE and BDECE students. The results obtained show that the latter have a higher level of skills and abilities in all the dimensions assessed. Despite this, and considering the small size of the differences, the need to design teaching activities aimed at strengthening the knowledge of future teachers in this area is suggested. This type of action will be particularly effective in increasing their level of awareness and sensitivity in matters of sustainability and, indirectly, in strengthening society's commitment to the achievement of the 2030 Agenda. It is also expected that the results will contribute to the improvement of the role of universities in this area. As social references, Higher Education institutions must assume their leadership and responsibility in this race towards a more sustainable and supportive future. In this sense, the analysis presented highlights the urgent need to embed, SDGs in the curricula of all degree programmes in an effective and real way, but especially in those that are responsible for promoting the values of equality, justice, and social peace.

Finally, with regard to the limitations of the study, it should be pointed out that it was carried out in the UA, which makes it difficult to generalise the results to other contexts. As a consequence, in future research it is proposed to extend the comparative study to other contexts. On the other hand, the use of a single data collection instrument, which was also based on the subjects' self-assessment, must be mentioned. Hence, we suggest that future studies combine the use of other techniques and tools to triangulate the results and to establish, with a greater degree of precision, the existence of possible differences. This prospective research will, in turn, be used to determine the influence of gender on the identified divergences.

Author Contributions: Conceptualization, G.M.-M. and M.U.-S.; methodology, S.B.-M.; software, M.J.H.-A.; validation, S.B.-M. and M.U.-S.; formal analysis, M.U.-S.; investigation, M.U.-S.; resources, M.J.H.-A.; data curation, M.J.H.-A.; writing-original draft preparation, G.M.-M. and M.U.-S.; writing—review and editing, G.M.-M.; visualization, S.B.-M.; supervision, G.M.-M.; project administration, M.U.-S.; funding acquisition, M.U.-S. All authors have read and agreed to the published version of the manuscript.

Funding: This research was supported by the Program Networks-I3CE of the Deputy Vice-Chancellor's Office for Quality and Educational Innovation of the University of Alicante, under Grant 5337Digital competencies of university students for e-sustainability. M.U.-S., M.J., H.-A. and G.M.-M. belong to the GIDU-EDUTIC/IN Research Group of the University of Alicante (VIGROB-0330FE) and S.B.-M. belongs to EDUCAFD Research Group of the University of Alicante. 
Institutional Review Board Statement: The study was conducted according to the guidelines of the Declaration of Helsinki and the Regulations of the Research Ethics Committee of the University of Alicante (https:/ / bit.ly/3BF6VFl, accessed on 10 October 2021).

Informed Consent Statement: Informed consent was obtained from all subjects involved in the study.

Data Availability Statement: The data presented in this study are available on request from the corresponding author. The data are not publicly available because they are presented together with other data that will be the subject of future research.

Acknowledgments: Our thanks go to the students for consenting to participate in this study. We also express our gratitude to the teachers of CDDC for their collaboration in this study.

Conflicts of Interest: The authors declare no conflict of interest. The funders had no role in the design of the study; in the collection, analyses, or interpretation of data; in the writing of the manuscript, or in the decision to publish the results.

\section{References}

1. Hogan, E.; Idowu, S.O. The drive towards global sustainability in the second millennium: An indispensable task for the survival of planet earth. In Current Global Practices of Corporate Social Responsibility; Idowu, S.O., Ed.; Springer: Cham, Switzerland, 2021; pp. 865-879.

2. The Sustainable Development Goals Report 2020. Available online: https://bit.ly/3f3FnRq (accessed on 12 June 2021).

3. Rahman, M.Z. Achieving sustainable development goals of Agenda 2030 in Bangladesh: The crossroad of the governance and performance. Public Adm. Policy 2021, 24, 195-211. [CrossRef]

4. Iwuoha, J.C.; Jude-Iwuoha, A.U. COVID-19: Challenge to SDG and globalization. Electron. Res. J. Soc. Sci. Humanit. 2020, 2, 103-115.

5. Shulla, K.; Voight, B.F.; Cibian, S.; Scandone, G.; Martinez, E.; Nelkovski, F.; Salehi, P. Effects of COVID-19 on the Sustainable Development Goals (SDGs). Discov. Sustain. 2021, 2, 1-19. [CrossRef]

6. Sustainable Development Goals. Decade of Action. Available online: https://bit.ly/3ysijCV (accessed on 5 April 2021).

7. Agirreazkuenaga, L. Education for Agenda 2030: What direction do we want to take going forward? Sustainability 2020, $12,2035$. [CrossRef]

8. Dlouhá, J.; Heras, R.; Mulà, I.; Perez, F.; Henderson, L. Competences to address SDGs in higher education-A reflection on the equilibrium between systemic and personal approaches to achieve transformative action. Sustainability 2019, 11, 3664. [CrossRef]

9. Martín, A.; Echegoyen, Y. Environmental attitudes in the literature classroom with preservice teachers. Profesorado Rev. Currículum Form. Del Profr. 2020, 24, 184-202. [CrossRef]

10. Olmos-Gómez, M.C.; Estrada-Vidal, L.I.; Ruiz-Garzón, F.; López-Cordero, R.; Mohamed-Mohand, L. Making future teachers more aware of issues related to sustainability: An assessment of best practices. Sustainability 2019, 11, 7222. [CrossRef]

11. Sánchez-Carracedo, F.; Moreno-Pino, F.M.; Romero-Portillo, D.; Sureda, B. Education for sustainable development in Spanish university education degrees. Sustainability 2021, 13, 1467. [CrossRef]

12. Albareda-Tiana, S.; García-González, E.; Jiménez-Fontana, R.; Solís-Espallargas, C. Implementing pedagogical approaches for ESD in initial teacher training at Spanish universities. Sustainability 2019, 11, 4927. [CrossRef]

13. Fuertes-Camacho, M.T.; Graell-Martín, M.; Fuentes-Loss, M.; Balaguer-Fàbregas, M.C. Integrating sustainability into higher education curricula through the project method, a global learning strategy. Sustainability 2019, 11, 767. [CrossRef]

14. Kalsoom, Q.; Khanam, A. Inquiry into sustainability issues by preservice teachers: A pedagogy to enhance sustainability consciousness. J. Clean. Prod. 2017, 164, 1301-1311. [CrossRef]

15. Lozano, A.; Figueredo, V. Los Objetivos de Desarrollo Sostenible en la formación de los futuros maestros: Uso de metodologías activas. Campo Abierto. Rev. Educ. 2021, 40, 245-257. [CrossRef]

16. Napal, M.; Mendióroz-Lacambra, A.M.; Peñalva, A. Sustainability teaching tools in the digital age. Sustainability 2020, $12,3366$. [CrossRef]

17. Ortega-Sánchez, D.; Gómez-Trigueros, I.M. Massive open online courses in the initial training of social science teachers: Experiences, methodological conceptions, and technological use for sustainable development. Sustainability 2019, 11, 578. [CrossRef]

18. Boulahrouz, M.; Medir, R.M.; Calabuig, S. Digital technologies and education for sustainable development. An analysis of scientific production. Pixel-Bit Rev. Medios y Educ. 2019, 54, 83-105.

19. Carrión-Martínez, J.J.; Luque-de la Rosa, A.; Fernández-Cerero, J.; Montenegro-Rueda, M. Information and Communications Technologies (ICTs) in education for sustainable development: A bibliographic review. Sustainability 2020, 12, 3288. [CrossRef]

20. González-Zamar, M.D.; Abad-Segura, E.; López-Meneses, E.; Gómez-Galán, J. Managing ICT for sustainable education: Research analysis in the context of higher education. Sustainability 2020, 12, 8254. [CrossRef]

21. Gong, X.; Zhang, J.; Zhang, H.; Cheng, M.; Wang, F.; Yu, N. Internet use encourages pro-environmental behavior: Evidence from China. J. Clean. Prod. 2020, 256, 120725. [CrossRef]

22. George, G.; Merrill, R.K.; Schillebeeckx, S.J.D. Digital sustainability and entrepreneurship: How digital innovations are helping tackle climate change and sustainable development. Enterpren. Theor. Pract. 2020, 45, 999-1027. [CrossRef] 
23. Altinoz, B.; Vasbieva, D.; Kalugina, O. The effect of information and communication technologies and total factor productivity on $\mathrm{CO}_{2}$ emissions in top 10 emerging market economies. Environ. Sci. Pollut. Res. 2021, 17, 1-10. [CrossRef]

24. Sovacool, B.K. When subterranean slavery supports sustainability transitions? Power, patriarchy, and child labor in artisanal Congolese cobalt mining. Extr. Ind. Soc. 2021, 8, 271-293. [CrossRef]

25. Becker, B. Educational ICT use outside school in the European Union: Disparities by social origin, immigrant background, and gender. J. Child. Media 2021, 1-20. [CrossRef]

26. Durand, A.; Zijlstra, T.; van Oort, N.; Hoogendoorn-Lanser, S.; Hoogendoorn, S. Access denied? Digital inequality in transport services. Transp. Rev. 2021, 1-26. [CrossRef]

27. Mubarak, F.; Suomi, R.; Kantola, S.P. Confirming the links between socio-economic variables and digitalization worldwide: The unsettled debate on digital divide. J. Inf. Commun. Ethics Soc. 2020, 18, 415-430. [CrossRef]

28. Scanlan, M. Reassessing the disability divide: Unequal access as the world is pushed online. Univers. Access Inf. Soc. 2021, 21, 1-11. [CrossRef]

29. Connect 2030. An Agenda for Connecting Everyone to a Better World. Available online: https:/ / bit.ly/2Wut3CL (accessed on 7 March 2021).

30. Sánchez, F.; Segalàs, J.; Vidal, E.; Martín, C.; López, D.; Climent, J.; Cabré, J. Mapa de la competencia sostenibilidad del proyecto EDINSOST. In XXIII Jornadas sobre la Enseñanza Universitaria de la Informática; Gómez, A., Rodríguez-Echevarría, R., Eds.; Asociación de Enseñantes Universitarios de la Informática: Extremadura, España, 2017; pp. 19-26.

31. Lozano-Díaz, A.; Fernández-Prados, J.S. Educating digital citizens: An opportunity to critical and activist perspective of sustainable development goals. Sustainability 2020, 12, 7260. [CrossRef]

32. Rodríguez-Marín, F.; Puig, M.; López-Lozano, L.; Guerrero, A. Early childhood preservice teachers' view of socio-environmental problems and its relationship to the Sustainable Development Goals. Sustainability 2020, 12, 7163. [CrossRef]

33. Dziminska, M.; Fijałkowska, J.; Sułkowski, L. A conceptual model proposal: Universities as culture change agents for sustainable development. Sustainability 2020, 12, 4635. [CrossRef]

34. Zamora-Polo, F.; Sánchez-Martín, J. Teaching for a better world. Sustainability and Sustainable Development Goals in the construction of a change-maker university. Sustainability 2019, 11, 4224. [CrossRef]

35. Gurbuz, I.B.; Ozkan, G. What's going on at the universities? How much has the research revealed university students' attitudes towards the environment? A case study of Bursa, Turkey. Appl. Ecol. Environ. Res. 2019, 17, 5109-5138. [CrossRef]

36. Segalàs, J.; Sánchez, F. El proyecto EDINSOST. Formación en las universidades españolas de profesionales como agentes de cambio para afrontar los retos de la sociedad. Rev. Educ. Ambient. Sostenibilidad 2019, 1, 1-16. [CrossRef]

37. Muñoz-Rodríguez, J.M.; Sánchez-Carracedo, F.; Barrón-Ruiz, A.; Serrate-González, S. Are we training in sustainability in higher education? Case study: Education degrees at the University of Salamanca. Sustainability 2020, 12, 4421. [CrossRef]

38. Zamora-Polo, F.; Sánchez-Martín, J.; Corrales-Serrano, M.; Espejo-Antúnez, L. What do university students know about Sustainable Development Goals? A realistic approach to the reception of this UN Program amongst the youth population. Sustainability 2019, 11, 3533. [CrossRef]

39. Valderrama-Hernández, R.; Alcántara, L.; Sánchez-Carracedo, F.; Caballero, D.; Serrate, S.; Gil-Doménech, D.; Vidal-Raméntol, S.; Miñano, R. ¿Forma en sostenibilidad el sistema universitario español? Visión del alumnado de cuatro universidades. Educ. XX1 2020, 23, 221-245. [CrossRef]

40. Ávalos, C.; Pérez-Escoda, A.; Monge, L. Lean Startup as a learning methodology for developing digital and research competencies. J. New Approaches Educ. Res. 2019, 8, 227-242. [CrossRef]

41. Grande-de-Prado, M.; Cañón-Rodríguez, R.; García-Martín, S. Digital security, how do teachers in training perceived themselves? J. Educ. Res. Innov. 2020, 14, 262-275. [CrossRef]

42. Gutiérrez, I.; Serrano, J.L. Evaluation and development of digital competence in future primary school teachers at the University of Murcia. J. New Approaches Educ. Res. 2016, 5, 51-56. [CrossRef]

43. Kuhn, C. Are students ready to (re)-design their personal learning environment? The case of the E-Dynamic. Space. J. New Approaches Educ. Res. 2017, 6, 11-19. [CrossRef]

44. Gewerc, A.; Montero, L. Professional knowledge and digital competency in teacher education. The case of elementary teacher education degree. Rev. Latinoam. Tecnol. Educ. 2015, 14, 31-43.

45. López-Gil, M.; Bernal, C. Teaching in the network society: Analysis of the digital competences of students in education at the University of Cádiz. J. Educ. Res. Innov. 2018, 11, 83-100.

46. Girón, V.; Cózar, R.; González-Calero, J.A. Análisis de la autopercepción sobre el nivel de competencia digital docente en la formación inicial de maestros/as. Rev. Electron. Interuniv. Form. Profr. 2019, 22, 193-218. [CrossRef]

47. Gutiérrez, J.J.; Cabero, J. A case study self-perception digital competence of the university student in bachelor's degrees in the pre-school teacher education and primary. Profesorado Rev. Currículum Form. del Profr. 2016, 20, 180-199.

48. Briones, E.; Palomera, R.; Gómez-Linares, A. Motivaciones, ideas implícitas y competencias del alumnado de Magisterio. Rev. Interuniv. Form. Profesorado 2021, 96, 49-68.

49. Estrada-Vidal, L.I.; Olmos-Gómez, M.C.; López-Cordero, R.; Ruiz-Garzón, F. The differences across future teachers regarding attitudes on social responsibility for sustainable development. Int. J. Environ. Res. Public Health 2020, 17, 5323. [CrossRef]

50. Marcos-Merino, J.M.; Corbacho-Cuello, I.; Hernández-Barco, M. Analysis of sustainability knowingness, attitudes and behavior of a Spanish pre-service primary teachers sample. Sustainability 2020, 12, 7445. [CrossRef] 
51. Colás-Bravo, P.; Magnoler, P.; Conde-Jiménez, J. Identification of levels of sustainable consciousness of teachers in training through an e-portfolio. Sustainability 2018, 10, 3700. [CrossRef]

52. Schina, D.; Esteve-González, V.; Usart, M.; Lázaro-Cantabrana, J.L.; Gisbert, M. The integration of sustainable development goals in educational robotics: A teacher education experience. Sustainability 2020, 12, 10085. [CrossRef]

53. Pipere, A. Journal of Teacher Education for Sustainability after the UN decade of education for sustainable development: Exploring for the future. J. Teach. Educ. Sustain. 2019, 21, 5-34. [CrossRef]

54. Roni, S.M.; Merga, M.K.; Morris, J.E. Conducting Quantitative Research in Education; Springer: Singapore, 2020.

55. Ministerio de Universidades. Datos y Cifras del Sistema Universitario Español. Publicación 2020-2021; Ministerio de Universidades: Madrid, España, 2021.

56. Sánchez, F.; Álvarez, M.J.; Barrón, A.; Caballero, D.; López, E.; Muñoz, J.M.; Lugo-Muñoz, M.; Sureda, B.; Vidal, E.; Vidal, S. Elaboración de un cuestionario para evaluar el nivel de sostenibilidad de los estudiantes de grados en ingeniería TIC. Actas de las JENUI 2018, 3, 141-148.

57. Mondal, H.; Mondal, S.; Ghosal, T.; Mondal, S. Using Google Forms for medical survey: A technical note. Int. J. Clin. Exp. Physiol. 2019, 5, 216-218. [CrossRef]

58. Rosenthal, R.; Rubin, D.B. Requivalent: A simple effect size indicator. Psychol. Methods 2003, 8, 492-496. [CrossRef] [PubMed]

59. Resolución de 7 de Marzo de 2012, de la Universidad de Alicante, por la que se Publica el Plan de Estudios de Graduado en Maestro en Educación Infantil. Available online: https:/ / bit.ly/3kw0D3O (accessed on 3 July 2021).

60. Resolución de 18 de Marzo de 2015, de la Universidad de Alicante, Por la Que SE Publica la Modificación Del Plan de Estudios de Graduado en Maestro en Educación Primaria. Available online: https:/ / bit.ly/3gJLydQ (accessed on 7 July 2021).

61. González, B.; Polo, E.; Jiménez, P.E. The feminization of early childhood education. About a study of male students at the University of Malaga. REDU. Rev. Docencia Univ. 2021, 19, 75-91. [CrossRef] 